\title{
Sustaining Soil Productivity by Integrated Plant Nutrient Management in Wheat Based Cropping System Under Rainfed Conditions
}

\author{
Mohiuddin Dilshad $^{\text {a* }}$, Mohammad Iqbal Lone ${ }^{\mathrm{b}}$, Ghulam Jilani' ${ }^{\mathrm{b}}$, Muhammad Azim Malik \\ Muhammad Yousaf $^{b}$, Rizwan Khalid ${ }^{a}$ and Fakhra Shamim ${ }^{b}$ \\ ${ }^{a}$ Soil Fertility Survey and Soil Testing Institute, Rawalpindi, Pakistan \\ ${ }^{\mathrm{b}}$ PMAS Arid Agriculture University, Rawalpindi, Pakistan
}

(received April 14, 2010; revised July 27, 2010; accepted August 18, 2010)

\begin{abstract}
The study of the use of organic (FYM) and inorganic (NPK) nutrient sources with biofertiliser on wheat-fallow and wheat-maize cropping system under rainfed environment revealed significant increase in biometric parameters of wheat during winter and summer seasons of two years. During both the seasons, application of $1 / 2$ NPK $+1 / 2$ FYM + Biopower (brand) produced the highest grain yield (3684 kg/ha) and (3781 kg/ha) of wheat with the maximum N uptake of $357 \mathrm{~kg} / \mathrm{ha}, \mathrm{P}$ uptake of $51 \mathrm{~kg} / \mathrm{ha}$ and $\mathrm{K}$ uptake of $215 \mathrm{~kg} / \mathrm{ha}$. Wheat-maize cropping system was found to be profitable economically with integrated use of mineral and organic and/or Biopower under rainfed conditions of Pakistan.
\end{abstract}

Keywords: integrated plant nutrient management, wheat-maize cropping, wheat-fallow cropping, rainfed area, biofertiliser, farm yard manure

\section{Introduction}

Growing concerns about the environmental consequences of use of mineral fertilizers and their future cost perspectives emphasize the need to develop new agricultural technologies that are sustainable both economically and ecologically. Use of chemical fertilizers alone does not sustain productivity under continuous intensive cropping, whereas inclusion of organic materials improves physical soil properties (Benbi et al., 1998), builds up soil fertility and increases crop yield (Yaduvanshi, 2003). Organic materials hold great promise due to their local availability as a source of multiple nutrients and ability to improve soil characteristics. According to several authors the improvement of fertility and quality of soil, especially under low input agricultural systems, requires the input of organic materials (Soumare et al., 2003; Ouedraogo et al., 2001). The effect of organic nutrients on crop yield is long term and not immediate. However, the use of biofertilisers along with organic/ inorganic materials effectively stimulates the supply and the release of nutrients from the nutrient sources. Combination of both $\mathrm{N}$ sources with effective microorganisms (EM) increased the NPK concentrations in cotton crop (Khaliq et al., 2006). Wu et al. (2005) observed that half the amount of biofertiliser applica-

*Author for correspondence; E-mail: mohiuddindilshad@yahoo.com tion had similar effects when compared with organic fertiliser and chemical fertiliser treatments.

Hence, the present experiment was carried out to evaluate the integrated use of organic and mineral fertilisers with biofertiliser 'Biopower' on the yield of wheat.

\section{Materials and Methods}

A field experiment pertaining to wheat based cropping system was conducted at the research farm of Soil Science and SWC Department of Arid Agriculture University, Rawalpindi. Split-plot design was used for two cropping system (CS) treatments in main plots and nine integrated plant nutrient management (IPNM) practices in subplots. All treatments were applied with three replications. The sub-plot size was $6 \mathrm{~m} \times 4 \mathrm{~m}$ $\left(24 \mathrm{~m}^{2}\right)$. The experiment was conducted in winter 2004-05 (Rabi season) with Triticum aestivum cv. Chakwal 97 as test crop followed by Zea mays cv. A gaiti 2002 in one main plot in summer of 2005 (Kharif season), while the second main plot remained fallow. All treatments of subplots were applied at the same rate to wheat and maize. The same experiment was repeated in winter 2005-06 and in summer 2006 on the same crops with identical treatments. National Institute for Biotechnology and Genetic Engineering (NIBGE), Faisalabad, Pakistan has developed a 
microbial inoculum 'Biopower'. The biofertiliser 'Biopower' was used for seed inoculation containing $\mathrm{N}$-fixing bacteria, belonging to genus Azotobacter, Azospirillum, Azoarcus and Zoogloea. Fallow plots were kept weed-free by repeated cultivation immediately followed by planking. There were two treatments of cropping systems: wheat-fallow $\left(\mathrm{CS}_{1}\right)$ and wheatmaize $\left(\mathrm{CS}_{2}\right)$. There were nine treatments of integrated plant nutrient management practices. These included: control (without NPK fertilizer, FYM or biofertiliser); half of recommended NPK; full dose of recommended NPK(120-90-60); FYM @ 20 t/ha; FYM on N requirement basis + make-up dose of P/K fertilizer; $1 \frac{1}{2}$ NPK + FYM @ 10 t/ha; 1/2 NPK + Biopower; 1/2 FYM + Biopower; and $1 / 2$ NPK $+1 / 2$ FYM + Biopower. The experimental site was located in the subtropical subhumid Pothwar plateau, Pakistan at an altitude of $513 \mathrm{~m}$ extending over latitude $32^{\circ} 10$ to $34^{\circ} 9 \mathrm{~N}$ and

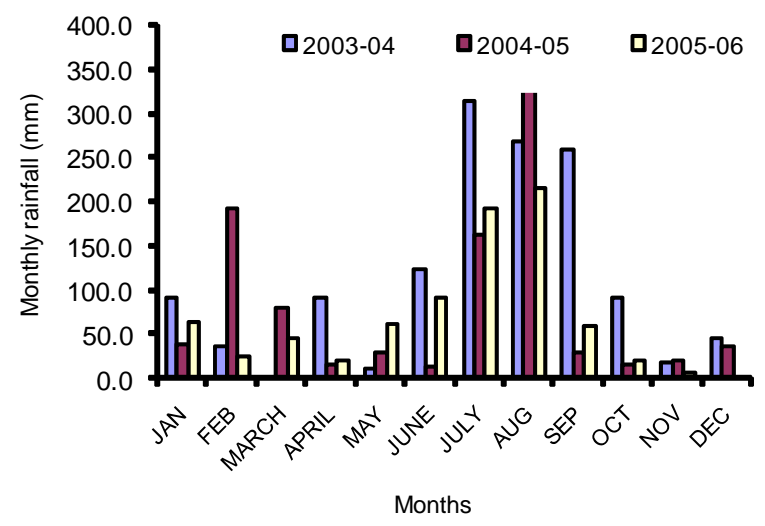

Fig. 1. Monthly rainfall during the study (2004-2006).

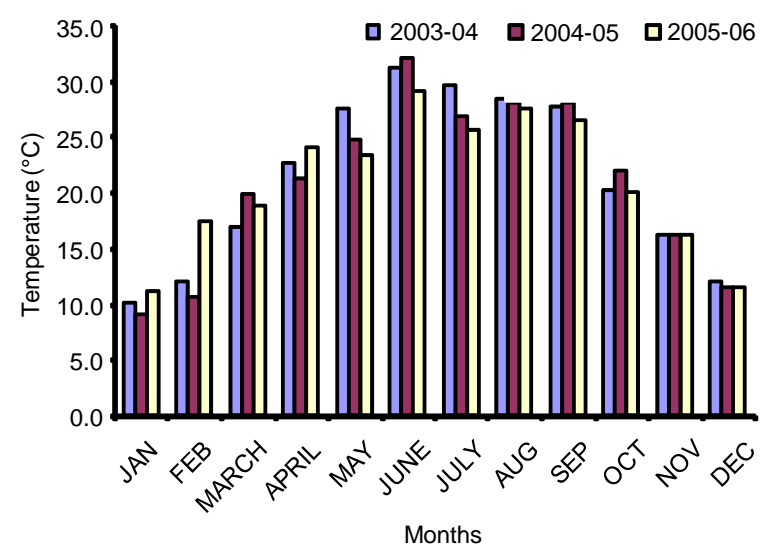

Fig. 2. Mean monthly temperature $\left({ }^{\circ} \mathrm{C}\right)$ during the study (2004-2006). longitude $71^{\circ} 10$ to $73^{\circ} 55 \mathrm{E}$ with 1.82 million hectares area. Fig. 1 and 2 present the data on mean monthly rainfall and temperature during the experimental period..

Chemical analysis. Composite soil sample were collected from the experimental field at two depths $(0-15 \mathrm{~cm}$ and $15-30 \mathrm{~cm}$ ) before sowing. One soil sample was collected for each treatment from the subplot before sowing and after harvest of wheat. Soil samples were analyzed for various physical and chemical characteristics. Soil texture was determined by hydrometer method as described by Koehler et al. (1984) and pH in soil water suspension (1:10) was determined with pH meter (McLean, 1984). Organic carbon was determined by the method given by Nelson and Sommers (1982). Total nitrogen was determined by Kjeldahl digestion method (AOAC, 1982). Available phosphorus was determined by Spectronic 601 as described by Soltanpur and Schwabe (1977). Ammonium acetateextractable potassium was determined by flame photometer (PFP, Jenway). Data for yield components and yield was recorded at physiological maturity of wheat. Plant and grain samples from individual treatments were analyzed for total nitrogen by Kjeldahl digestion method; phosphorus was determined by AB-DTPA extractable-P method and total $\mathrm{K}$ concentration, by flame photometer (Ryan et al., 2001).

Statistical and economic analysis. Growth, yield and soil parameters were recorded and then analyzed statistically according to standard statistical procedures described by Sokal and Rohlf (1997). Data showing significant difference at $\mathrm{P}=0.05$ was put to comparison of treatment means by Duncan's multiple range test. All the data was processed using MSTAT software for statistical analysis. For economic analysis, after considering the cost of fertilizer N, P, K, farmyard manure and biofertilizer 'Biopower' application, income from seed yield was used for economic analysis (CIMMYT, 1988) using the formula:

$$
\begin{array}{ll}
\text { Value cost ratio = } & \begin{array}{l}
\text { value of increased yield } \\
\text { obtained/cost of mineral/ } \\
\text { organic sources. }
\end{array}
\end{array}
$$

\section{Results and Discussion}

Composite soil sample analysis before the start of the experiment showed that the soil was sandy loam in texture with reaction of 7.8 and ECe of $0.25 \mathrm{dS} / \mathrm{m}$. It had low soil organic carbon of $0.32 \mathrm{~g} / 100 \mathrm{~g}$. The total soil nitrogen, available $\mathrm{P}$ and extractable $\mathrm{K}$ were 
estimated as $152,3.45$ and $80 \mu \mathrm{g} / \mathrm{g}$, respectively, showing low fertility status of soil (Table 1 ).

Table 1. Physical and chemical properties of composite soil samples before the start of experiment

\begin{tabular}{lll}
\hline \hline Soil series : Rawal; Soil order : Inceptisol; Parent material : Loess \\
\cline { 2 - 3 } & \multicolumn{2}{c}{ Soil depth } \\
\cline { 2 - 3 } Parameter & $0-15 \mathrm{~cm}$ & $15-30 \mathrm{~cm}$ \\
\hline Clay (\%) & 16 & 17 \\
Silt (\%) & 39 & 40 \\
Sand (\%) & 45 & 43 \\
Soil texture & Sandy loam & Sandy loam \\
Soil pH & 7.80 & 7.91 \\
EC $(\mathrm{dS} / \mathrm{m})$ & 0.25 & 0.21 \\
Bulk density (g/cc) & 1.40 & 1.53 \\
Soil moisture $(\mathrm{g} / 100 \mathrm{~g})$ & 8.82 & 9.2 \\
Total N $(\mu \mathrm{g} / \mathrm{g})$ & 152 & 154 \\
Organic C $(\mathrm{g} / 100 \mathrm{~g})$ & 0.32 & 0.33 \\
Available P $(\mu \mathrm{g} / \mathrm{g})$ & 3.45 & 3.55 \\
Extractable K $(\mu \mathrm{g} / \mathrm{g})$ & 80 & 85 \\
\hline \hline
\end{tabular}

Yield and yield components of wheat. Plant height. The height of a plant is an expression of inherited biological and environmental factors. During 2004-05, the application of $1 / 2 \mathrm{NPK}+1 / 2 \mathrm{FYM}+\operatorname{Biopower}\left(\mathrm{T}_{9}\right)$ produced maximum average plant height of $108.9 \mathrm{~cm}$ followed by $106.4 \mathrm{~cm}$ due to treatment of $1 / 2 \mathrm{NPK}+1 / 2$ $\operatorname{FYM}\left(\mathrm{T}_{6}\right)$. The recommended NPK treatment $\left(\mathrm{T}_{3}\right)$ produced $104.6 \mathrm{~cm}$ of plant height, which was statistically at par with the treatment $\left(\mathrm{T}_{6}\right)$ and $\left(\mathrm{T}_{8}\right)$. The results during 2005-06 showed that application of $1 / 2$ NPK + $1 / 2 \mathrm{FYM}+$ Biopower $\left(\mathrm{T}_{9}\right)$ caused the highest plant height of $111.8 \mathrm{~cm}$ followed by $110.1 \mathrm{~cm}$ in $\mathrm{T}_{3}$, which were at par with the other, statistically. The plant height due to $T_{3}$ and $T_{6}$ were also statistically at par (Table 2). Maximum plant height by $\mathrm{T}_{9}(1 / 2 \mathrm{NPK}+1 / 2 \mathrm{FYM}+$ Biopower) was due to the improved availability of plant nutrients through Biopower. Rashid et al. (1998) and Ahmed et al. (1998) also reported that Integrated plant nutrient management (IPNM) produced higher plant height for wheat crop in rainfed areas. Chatha et al., (2006) also estimated that combined use of mineral and organic fertilizers resulted in higher plant height of wheat and maize in rainfed conditions. Many earlier researchers had also recorded that combined use of organic and chemical fertilizer to soil increased efficiency of chemical fertilizer and crop yield significantly (Bhatti, 2006; Jadoon et al., 2004; Nawaz et al., 2000).

Biological yield. During the first year (2004-05), application of $1 / 2 \mathrm{NPK}+1 / 2 \mathrm{FYM}+$ Biopower $\left(\mathrm{T}_{9}\right)$

Table 2. Effect of integrated use of organic and mineral fertilisers and/or biopower on plant height of wheat during 2004-06

\begin{tabular}{|c|c|c|c|c|c|c|}
\hline \multirow[t]{3}{*}{ Treatments } & & \multicolumn{4}{|c|}{ Plant height $(\mathrm{cm})$} & \\
\hline & \multicolumn{3}{|c|}{ 2004-05 } & \multicolumn{3}{|c|}{$2005-06$} \\
\hline & $\overline{\mathrm{CS}_{1}}$ & $\mathrm{CS}_{2}$ & Mean & $\mathrm{CS}_{1}$ & $\mathrm{CS}_{2}$ & Mean \\
\hline $\mathrm{T}_{1}$ Control & $96.7^{\mathrm{g}}$ & $92.9^{\mathrm{h}}$ & $94.8^{\mathrm{G}}$ & 84.5 & 82.1 & $83.3^{\mathrm{F}}$ \\
\hline $\mathrm{T}_{2}$ NPK (60-45-30) kg/ha & $98.5^{\mathrm{fg}}$ & $96.8^{\mathrm{g}}$ & $97.7^{\mathrm{F}}$ & 96.2 & 95.8 & $96.0^{\mathrm{E}}$ \\
\hline $\mathrm{T}_{3}$ NPK(120-90-60) kg/ha & $103.3^{\text {cde }}$ & $105.9^{\mathrm{bc}}$ & $104.6^{\mathrm{BC}}$ & 111.6 & 108.6 & $110.1^{\mathrm{AB}}$ \\
\hline $\mathrm{T}_{4}$ Full FYM @ $20 \mathrm{t} / \mathrm{ha}$ & $100.2^{\text {ef }}$ & $101.2^{\text {def }}$ & $100.7^{\mathrm{E}}$ & 105.0 & 102.3 & $103.6^{\mathrm{CD}}$ \\
\hline $\mathrm{T}_{5} \mathrm{FYM}^{*}$ & $103.6^{\mathrm{cd}}$ & $103.5^{\mathrm{cd}}$ & $103.5^{\mathrm{CD}}$ & 107.3 & 104.4 & $106.1^{\mathrm{CD}}$ \\
\hline $\mathrm{T}_{6} 1 / 2 \mathrm{NPK}+1 / 2 \mathrm{FYM}$ & $106.4^{\mathrm{cd}}$ & $106.5^{\mathrm{bc}}$ & $106.4^{\mathrm{B}}$ & 109.6 & 105.0 & $107.3^{\mathrm{BC}}$ \\
\hline $\mathrm{T}_{7} 1 / 2 \mathrm{NPK}+$ Biopower & $101.3^{\text {def }}$ & $102.7^{\mathrm{de}}$ & $102.0^{\mathrm{DE}}$ & 101.5 & 103.7 & $102.6^{\mathrm{D}}$ \\
\hline $\mathrm{T}_{8} \quad 1 / 2 \mathrm{FYM}+$ Biopower & $103.3^{\text {cde }}$ & $103.8^{\mathrm{cd}}$ & $103.6^{\mathrm{CD}}$ & 105.7 & 104.7 & $105.2^{\mathrm{CD}}$ \\
\hline $\mathrm{T}_{9} 1 / 2 \mathrm{NPK}+1 / 2 \mathrm{FYM}+\mathrm{BP}$ & $107^{\mathrm{b}}$ & $110.9^{\mathrm{a}}$ & $108.9^{\mathrm{A}}$ & 112.6 & 111.1 & $111.8^{\mathrm{A}}$ \\
\hline Mean & $102.2^{\mathrm{Y}}$ & $102.7^{\mathrm{X}}$ & - & $103.8 \mathrm{~ns}$ & 101.9 ns & - \\
\hline Analysis of variance & P-value & LSD & SE & $\mathrm{P}$-value & LSD & SE \\
\hline Treatment (T) & $<0.001$ & 1.995 & 0.6941 & $<0.001$ & 3.467 & 1.206 \\
\hline Cropping system (CS) & ns & & & 0.0253 & & \\
\hline $\mathrm{T} \times \mathrm{CS}$ & 0.02 & 2.821 & 0.9817 & ns & & \\
\hline $\mathrm{CV}( \pm \%)$ & 1.66 & - & - & 2.87 & - & - \\
\hline
\end{tabular}

CS = cropping system; biofertiliser biopower (seed inoculation at sowing); NPK @ 120-90-60 kg/ha; FYM (farm yard manure), @ 20 t/ha; FYM* = N equivalent + P make up dose; data are average of three replications; means followed by the same superscripts are not significantly different $(\mathrm{P}<0.05$; DMR test) from each other. 
produced the highest biological yield of $9698 \mathrm{~kg} / \mathrm{ha}$ followed by $8899 \mathrm{~kg} / \mathrm{ha}$ by treatment of $1 / 2 \mathrm{NPK}+1 / 2$ FYM; difference between these treatments was significant (Table 3). Mineral fertilizer NPK treatment $\left(\mathrm{T}_{3}\right)$ yielded $8622 \mathrm{~kg} / \mathrm{ha}$, which was significantly lower to both the $T_{9}$ and the $T_{6}$ treatments. Application of FYM with $\mathrm{P}$ make-up dose produced biological yield of $7518 \mathrm{~kg} / \mathrm{ha}$, which was significantly higher than the $\mathrm{T}_{4}$ that gave $7140 \mathrm{~kg} / \mathrm{ha}$. The $1 \frac{1}{2} \mathrm{FYM}+$ Biopower treatment $\left(T_{8}\right)$ gave biological yield of $7206 \mathrm{~kg} / \mathrm{ha}$, which was statistically at par with the $T_{4}$. Biopower with $1 / 2$ NPK produced a biological yield of $6969 \mathrm{~kg} / \mathrm{ha}$ that was significantly lower than the $T_{8}$

The results during 2005-06 showed that the highest biological yield of $9381 \mathrm{~kg} / \mathrm{ha}$ was produced by $\mathrm{T}_{9}$, which was statistically at par with the biological yield of $9335 \mathrm{~kg} / \mathrm{ha}$ by $\mathrm{T}_{6}$ and $8753 \mathrm{~kg} / \mathrm{ha}$ due to NPK fertilisers $\left(\mathrm{T}_{3}\right)$. Application of FYM $\left(\mathrm{T}_{4}\right.$ and $\left.\mathrm{T}_{5}\right)$ produced biological yield of $6725 \mathrm{~kg} / \mathrm{ha}$ and $6308 \mathrm{~kg} / \mathrm{ha}$, respectively, which were statistically at par with one other.

Significant interaction between integrated nutrient management practices and cropping system (Table 3) was observed during 2004-05, while this interaction was nonsignificant during 2005-06. Higher biological yield was produced in $\mathrm{CS}_{2}$ than $\mathrm{CS}_{1}$ during 2004-05 and 2005-06. However, yield of 2005-06 was lower than that of 2004-05 with significant difference between the two cropping systems for the first year and the second year of wheat. It may be due to the low rainfall received during the second crop year (Fig. 1). This is evident from the integrated use of organic and mineral fertilisers and/or Biopower showing better performance regarding the biological yield of wheat. Integrated plant nutrient management had advantage over the sole application of mineral and organic and/or biofertilisers. Ahmed et al. (1998) reported that IPNM produced higher biological yield of wheat in rainfed areas. Highest biological yield produced by $\mathrm{T}_{9}(1 / 2 \mathrm{NPK}$ + $1 / 2$ FYM + Biopower) may be due to better availability of plant nutrients (Hafeez et al., 2002). Khaliq et al. (2006) also reported higher growth and yield of cotton by integrated use of organic and inorganic nutrient sources with the effective microorganisms.

Grain yield. Grain yield in wheat Triticum aestivum L. is the result of a number of complex morphological and physiological processes affecting each other. During 2004-05, application of $1 / 2$ NPK $+1 / 2$ FYM + Biopower $\left(\mathrm{T}_{9}\right)$ produced the highest grain yield of $3684 \mathrm{~kg} / \mathrm{ha}$ followed by the grain yield of $3492 \mathrm{~kg} / \mathrm{ha}$

Table 3. Effect of integrated use of organic and mineral fertilisers and/or biopower on biological yield of wheat during 2004-06

\begin{tabular}{|c|c|c|c|c|c|c|}
\hline \multirow[t]{3}{*}{ Treatments } & & \multicolumn{4}{|c|}{ Yield (kg/ha) } & \\
\hline & \multicolumn{3}{|c|}{ 2004-05 } & \multicolumn{3}{|c|}{ 2005-06 } \\
\hline & $\mathrm{CS}_{1}$ & $\mathrm{CS}_{2}$ & Mean & $\mathrm{CS}_{1}$ & $\mathrm{CS}_{2}$ & Mean \\
\hline $\mathrm{T}_{1}$ Control & $4290^{\mathrm{i}}$ & $4255^{\mathrm{i}}$ & $4273^{\mathrm{H}}$ & 4200 ns & $4106 \mathrm{~ns}$ & $4153^{\mathrm{D}}$ \\
\hline $\mathrm{T}_{2} \quad \mathrm{NPK}(60-45-30) \mathrm{kg} / \mathrm{ha}$ & $6149^{\mathrm{h}}$ & $6200^{\mathrm{h}}$ & $6175^{\mathrm{G}}$ & 6066 & 6160 & $6113^{\mathrm{C}}$ \\
\hline $\mathrm{T}_{3} \quad \mathrm{NPK}(120-90-60) \mathrm{kg} / \mathrm{ha}$ & $8565^{c}$ & $8679^{c}$ & $8622^{\mathrm{C}}$ & 8580 & 8926 & $8753^{\mathrm{A}}$ \\
\hline $\mathrm{T}_{4}$ Full FYM @20t/ha & $7199^{\mathrm{e}}$ & $7140^{\mathrm{e}}$ & $7170^{\mathrm{E}}$ & 6351 & 6264 & $6308^{\mathrm{BC}}$ \\
\hline $\mathrm{T}_{5} \mathrm{FYM}^{*}$ & $7505^{d}$ & $7531^{\mathrm{d}}$ & $7518^{\mathrm{D}}$ & 6637 & 6812 & $6725^{\mathrm{BC}}$ \\
\hline $\mathrm{T}_{6} \quad 1 / 2 \mathrm{NPK}+1 / 2 \mathrm{FYM}$ & $8789^{b}$ & $9010^{\mathrm{b}}$ & $8899^{\text {B }}$ & 9290 & 9380 & $933^{5 \mathrm{~A}}$ \\
\hline $\mathrm{T}_{7} \quad 1 / 2 \mathrm{NPK}+$ Biopower (BP) & $6819^{\mathrm{g}}$ & $7119^{\mathrm{g}}$ & $6969^{\mathrm{F}}$ & 6575 & 6575 & $6575^{\mathrm{BC}}$ \\
\hline $\mathrm{T}_{8} \quad 1 / 2 \quad \mathrm{FYM}+\mathrm{BP}$ & $7176^{\mathrm{f}}$ & $7236^{\mathrm{g}}$ & $7206^{\mathrm{E}}$ & 7040 & 6776 & $6908^{\mathrm{B}}$ \\
\hline \multirow[t]{2}{*}{$\mathrm{T}_{9} 1 / 2 \mathrm{NPK}+1 / 2 \mathrm{FYM}+\mathrm{BP}$} & $9641^{\mathrm{a}}$ & $9755^{\mathrm{a}}$ & $9698^{\mathrm{A}}$ & 9226 & 9535 & $9381^{\mathrm{A}}$ \\
\hline & & $7348^{\mathrm{Y}}$ & $7436^{\mathrm{x}}$ & & 7094 & 7151 \\
\hline Analysis of variances & P-value & LSD & SE & P-value & LSD & SE \\
\hline Treatment (T) & $<0.001$ & 109.0 & 37.92 & $<0.001$ & 588.8 & 186.9 \\
\hline Cropping system (CS) & 0.0014 & & & ns & & \\
\hline $\mathrm{T} \times \mathrm{CS}$ & 0.0418 & & & ns & & \\
\hline $\mathrm{CV}( \pm \%)$ & 1.26 & & & 6.43 & & \\
\hline
\end{tabular}

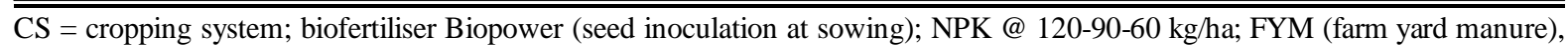
@ 20 t/ha; FYM* = (N equivalent + P make up dose); data are average of three replications; means followed by the same superscripts are not significantly different $(\mathrm{P}<0.05$; DMR test) from each other. 
by the treatment $T_{6}(1 / 2 \mathrm{NPK}+1 / 2 \mathrm{FYM})$, while the use of the recommended NPK dose produced $3292 \mathrm{~kg} / \mathrm{ha}$ grain yield which were significant. The difference between the highest and the lowest grain yield obtained was $1938 \mathrm{~kg} / \mathrm{ha}$. There was significant difference between $\mathrm{CS}_{1}$ and $\mathrm{CS}_{2}$ for the average of all the nine treatments (Table 4).

The results during 2005-06 showed that application of $1 / 2 \mathrm{NPK}+1 / 2 \mathrm{FYM}+$ Biopower $\left(\mathrm{T}_{9}\right)$ caused the highest grain yield of $3781 \mathrm{~kg} / \mathrm{ha}$, which was statistically significant to all the nine treatments. The application of $1 / 2$ NPK + 1 1 2 FYM produced significantly lower grain yield of $3611 \mathrm{~kg} /$ ha than $\mathrm{T}_{9}$, while $\mathrm{T}_{3}$ produced significantly lower grain yield of $3424 \mathrm{~kg} / \mathrm{ha}$ than $\mathrm{T}_{6}$. The grain yield produced during 2005-06 was higher than that produced during 2004-05, depicting nonsignificant difference between the two cropping systems for the first year and the second year of wheat. There was no effect of cropping system on grain yield of wheat during both the years; however, lower values of grain yield were recorded in 2004-05.

A nonsignificant interaction between the integrated nutrient management practices and the cropping system (Table 4) was observed in both the years. The highest grain yield was observed when $1 / 2 \mathrm{NPK}+1 / 2$
$\mathrm{FYM}+$ Biopower were applied in $\mathrm{CS}_{1}$ and $\mathrm{CS}_{2}$. However, during 2005-06, $\mathrm{CS}_{1}$ produced higher grain yield than $\mathrm{CS}_{2}$. The reason might be that after the harvest of wheat in 2004-05, the field was kept fallow $\left(\mathrm{CS}_{1}\right)$, while in $\mathrm{CS}_{2}$, maize was grown which might have depleted the soil of nutrients and moisture. The results showed that integrated use of organic and mineral fertilisers and/or biofertilisers showed better performance regarding grain yield of wheat. Both FYM treatments $\left(\mathrm{T}_{4}\right.$ and $\left.\mathrm{T}_{5}\right)$ showed significant increase in grain yield. Results of previous studies indicated that use of organic sources as FYM produced equivalent or more plant biomass and grain yield of wheat as the application of inorganic fertilizers alone (Alam and Shah, 2003; Bakhtiar et al., 2002; Khanum et al., 2001). Chatha et al. (2006) also reported that the combined use of mineral and organic fertiliser produced higher grain yield of wheat crop in rainfed areas. Biofertilser 'Biopower' treatments $\left(T_{7}\right.$ and $\left.T_{8}\right)$ showed significant increase in grain yield over $\mathrm{T}_{3}$ depicting Biopower response (Hafeez et al., 2002). The highest grain yield in IPNM treatment $T_{9}$ may be due to better availability of plant nutrients, while mineral fertilizers released nutrients readily to soil (Ahmad et al., 2002). Increase in grain yield due to IPNM can be attributed to improvement of organic matter content (Singh and Swarup,

Table 4. Effect of integrated use of organic and mineral fertilisers and/or biopower on grain yield of wheat during 2004-2006

\begin{tabular}{|c|c|c|c|c|c|c|}
\hline \multirow[t]{3}{*}{ Treatments } & \multicolumn{6}{|c|}{ Yield (kg/ha) } \\
\hline & \multicolumn{3}{|c|}{ 2004-05 } & \multicolumn{3}{|c|}{$2005-06$} \\
\hline & $\mathrm{CS}_{1}$ & $\mathrm{CS}_{2}$ & Mean & $\mathrm{CS}_{1}$ & $\mathrm{CS}_{2}$ & Mean \\
\hline $\mathrm{T}_{1}$ Control & $1654 \mathrm{~ns}$ & 1636 ns & $1646^{\mathrm{H}}$ & $1580 \mathrm{~ns}$ & $1466 \mathrm{~ns}$ & $1523^{\mathrm{I}}$ \\
\hline $\mathrm{T}_{2}$ NPK $(60-45-30) \mathrm{kg} / \mathrm{ha}$ & 2388 & 2408 & $2399^{\mathrm{G}}$ & 2333 & 2314 & $2324^{\mathrm{H}}$ \\
\hline $\mathrm{T}_{3} \quad \mathrm{NPK}(120-90-60) \mathrm{kg} / \mathrm{ha}$ & 3266 & 3317 & $3292^{\mathrm{C}}$ & 3429 & 3418 & $3424^{\mathrm{C}}$ \\
\hline $\mathrm{T}_{4}$ Full FYM@20 t/ha & 2830 & 2804 & $2818^{\mathrm{E}}$ & 2930 & 3017 & $2974^{\mathrm{E}}$ \\
\hline $\mathrm{T}_{5}$ FYM $^{*}$ & 2974 & 2936 & $2956^{\mathrm{D}}$ & 3173 & 3145 & $3159^{\mathrm{D}}$ \\
\hline $\mathrm{T}_{6} \quad 1 / 2 \mathrm{NPK}+1 / 2 \mathrm{FYM}$ & 3450 & 3533 & $3492^{\mathrm{B}}$ & 3625 & 3597 & $3611^{\mathrm{B}}$ \\
\hline $\mathrm{T}_{7} 1 / 2 \mathrm{NPK}+$ Biopower & 2638 & 2771 & $2705^{\mathrm{F}}$ & 2695 & 2624 & $2660^{\mathrm{G}}$ \\
\hline $\mathrm{T}_{8} 1 / 2 \mathrm{FYM}+$ Biopower & 2826 & 2837 & $2832^{\mathrm{E}}$ & 2858 & 2765 & $2812^{\mathrm{F}}$ \\
\hline $\mathrm{T}_{9} 1 / 2 \mathrm{NPK}+1 / 2 \mathrm{FYM}+\mathrm{BP}$ & 3675 & 3692 & $3684^{\mathrm{A}}$ & 3793 & 3768 & $3781^{\mathrm{A}}$ \\
\hline Mean & 2856 & 2881 & & 2935 & 2901 & \\
\hline Analysis of variances & $\mathrm{P}$-value & LSD & $\mathrm{SE}$ & P-value & LSD & SE \\
\hline Treatment (T) & $<0.001$ & 55 & 19 & $<0.001$ & 66 & 23 \\
\hline Cropping system (CS) & 0.0519 & & & 0.0357 & & \\
\hline $\mathrm{T} \times \mathrm{CS}$ & $0.068 \mathrm{~ns}$ & & & $0.165 \mathrm{~ns}$ & & \\
\hline $\mathrm{CV}( \pm \%)$ & 1.64 & & & 1.93 & & \\
\hline
\end{tabular}


2001) and consequently improvement of physical properties particularly water holding capacity of soil (Hati et al., 2007). Khaliq et al. (2006) also recorded higher growth and yield of cotton by integrated use of organic and inorganic nutrient sources with effective microorganisms. Ahmad et al. (2008); Bhatti (2006) and Wu et al. (2005) also documented that combined use of organic and mineral fertilisers produced better grain yield.

NPK uptake. The uptake of macronutrients like N, P and $\mathrm{K}$ is the direct indication of the growth and the biomass production. During 2004-05, application of $1 / 2 \mathrm{NPK}+1 / 2 \mathrm{FYM}+$ Biopower $\left(\mathrm{T}_{9}\right)$ recorded maximum N uptake of $357 \mathrm{~kg} / \mathrm{ha}$ followed by $313 \mathrm{~kg} / \mathrm{ha}$ by recommended dose of NPK fertiliser treatment $\left(T_{3}\right)$. Maximum $\mathrm{P}$ uptake of $51 \mathrm{~kg} / \mathrm{ha}$ was recorded by $\mathrm{T}_{9}$ followed by $P$ uptake of $49 \mathrm{~kg} / \mathrm{ha}$ in mineral fertiliser treatment $\left(\mathrm{T}_{3}\right)$. Maximum $\mathrm{K}$ uptake of $215 \mathrm{~kg} / \mathrm{ha}$ was recorded by $T_{9}$ followed by $\mathrm{K}$ uptake of $195 \mathrm{~kg} / \mathrm{ha}$ by mineral fertilisers treatment $\left(T_{3}\right)$ as depicted in Table 5.

During 2005-06, application of $1 \frac{1}{2}$ NPK + 1/2 FYM + Biopower $\left(\mathrm{T}_{9}\right)$ recorded maximum $\mathrm{N}$ uptake of $367 \mathrm{~kg} / \mathrm{ha}$ followed by $\mathrm{N}$ uptake of $344 \mathrm{~kg} /$ ha by the recommended dose of NPK fertiliser treatment $\left(\mathrm{T}_{3}\right)$. Maximum $\mathrm{P}$ uptake of $55 \mathrm{~kg} / \mathrm{ha}$ was recorded by $\mathrm{T}_{9}$ followed by $\mathrm{P}$ uptake of $53 \mathrm{~kg} / \mathrm{ha}$ by $\mathrm{T}_{3}$. Maximum $\mathrm{K}$ uptake of $210 \mathrm{~kg} / \mathrm{ha}$ was recorded by $\mathrm{T}_{9}$ followed by $\mathrm{K}$ uptake of $207 \mathrm{~kg} /$ ha by mineral fertiliser treatment $\left(\mathrm{T}_{3}\right)$.

The results showed that integrated use of organic and mineral fertilizers and/or biofertiliser rendered better performance regarding grain yield of wheat. Integrated plant nutrient management had advantage over the sole application of mineral and organic and/or biofertiliser. During 2004-05, application of $1 \frac{1}{2}$ NPK + $1 / 2$ FYM + Biopower $\left(\mathrm{T}_{9}\right)$ recorded 14, 4 and 10\% increase in uptake of $\mathrm{N}, \mathrm{P}$ and $\mathrm{K}$, respectively, by wheat over mineral fertiliser treatment $\left(\mathrm{T}_{3}\right)$, while during 2005-06, application of $1 \frac{1}{2}$ NPK + 1/2 FYM + Biopower $\left(\mathrm{T}_{9}\right)$ recorded 6.5, 3.8 and 1.5\% increase in uptake of $\mathrm{N}, \mathrm{P}$ and $\mathrm{K}$, respectively by wheat over mineral fertiliser treatment $\left(\mathrm{T}_{3}\right)$. Integrated plant nutrient treatment, especially with Biopower, improved NPK uptake over mineral fertilisers (Hafeez et al., 2002; Bakhsh et al., 2001).

The results of this experiment revealed that full dose of mineral NPK fertilisers caused maximum uptake of $\mathrm{N}, \mathrm{P}$ and $\mathrm{K}$ nutrients by both the wheat and the maize plants in both the growing seasons. Biofertiliser treatments, especially those with Biopower, improved NPK uptake over half the dose of NPK. This was due to the fact that Biopower contained four $\mathrm{N}$-fixing bacteria, which resulted in increased availability of nutrients to wheat plants. Microbial inoculums not only increased the nutritional assimilation of wheat plants (total N, P and $\mathrm{K}$ ) but also improved soil properties, which lead to better vegetative growth and crop yield (Ahmad et al., 2008).

The economic analysis. The economic analysis of the cropping systems revealed that wheat-maize cropping system was profitable with the integrated use of mineral, organic and/or biofertiliser under rainfed conditions. The results indicated that organic sources

Table 5. Effect of integrated plant nutrient management on NPK uptake (kg/ha) of wheat

\begin{tabular}{|c|c|c|c|c|c|c|}
\hline \multirow[t]{3}{*}{ Treatments } & \multicolumn{6}{|c|}{ NPK uptake (kg/ha) } \\
\hline & \multicolumn{3}{|c|}{ 2004-05 } & \multicolumn{3}{|c|}{ 2005-06 } \\
\hline & $\mathrm{N}$ & $\mathrm{P}$ & $\mathrm{K}$ & $\mathrm{N}$ & $\mathrm{P}$ & $\mathrm{K}$ \\
\hline $\mathrm{T}_{1}$ Control & 77 & 15 & 66 & 67 & 17 & 62 \\
\hline $\mathrm{T}_{2}$ NPK (60-45-30) kg/ha & 134 & 25 & 112 & 131 & 27 & 110 \\
\hline $\mathrm{T}_{3}$ NPK(120-90-60) kg/ha & 313 & 49 & 195 & 344 & 53 & 207 \\
\hline T 4 Full FYM @ 20 t/ha & 221 & 37 & 160 & 205 & 34 & 145 \\
\hline $\mathrm{T}_{5}$ FYM* & 237 & 43 & 174 & 222 & 39 & 157 \\
\hline $\mathrm{T}_{6} 1 / 2 \mathrm{NPK}+1 / 2 \mathrm{FYM}$ & 299 & 45 & 194 & 329 & 49 & 206 \\
\hline $\mathrm{T}_{7} 1 / 2 \mathrm{NPK}+$ Biopower & 200 & 30 & 148 & 200 & 28 & 139 \\
\hline $\mathrm{T}_{8} 1 / 2 \mathrm{FYM}+$ Biopower & 209 & 31 & 153 & 217 & 30 & 146 \\
\hline $\mathrm{T}_{9} 1 / 2 \mathrm{NPK}+1 / 2 \mathrm{FYM}+$ Biopower & 357 & 51 & 215 & 367 & 55 & 210 \\
\hline
\end{tabular}

CS = cropping system; biofertiliser biopower (seed inoculation at sowing); NPK @ 120-90-60 kg/ha; FYM (farm yard manure), @ 20 t/ha; FYM* = N equivalent + P make up dose; data are average of three replications $(\mathrm{P}<0.05$; DMR test). 
Table 6. Value cost ratio (VCR) due to integrated plant nutrient management on seed yield of wheat

\begin{tabular}{|c|c|c|c|c|c|c|}
\hline \multirow[t]{3}{*}{ Treatments } & & \multicolumn{5}{|c|}{ Value cost ratio } \\
\hline & & \multicolumn{2}{|l|}{$2004-05$} & & \multicolumn{2}{|c|}{$2005-06$} \\
\hline & $\mathrm{CS}_{1}$ & & $\mathrm{CS}_{2}$ & & $\mathrm{CS}_{1}$ & $\mathrm{CS}_{2}$ \\
\hline $\mathrm{T}_{1}$ Control & - & & - & & - & - \\
\hline $\mathrm{T}_{2}$ NPK $(60-45-30) \mathrm{kg} / \mathrm{ha}$ & 1.84 & & 1.94 & & 1.89 & 2.13 \\
\hline $\mathrm{T}_{3}$ NPK(120-90-60) kg/ha & 2.02 & & 2.11 & & 2.32 & 2.45 \\
\hline $\mathrm{T}_{4}$ Full FYM @ $20 \mathrm{t} / \mathrm{ha}$ & 1.18 & & 1.07 & & 1.35 & 1.55 \\
\hline $\mathrm{T}_{5} \mathrm{FYM}^{*}$ & 1.28 & & 1.26 & & 1.54 & 1.62 \\
\hline $\mathrm{T}_{6} \quad 1 / 2 \mathrm{NPK}+1 / 2 \mathrm{FYM}$ & 2.00 & & 2.11 & & 2.28 & 2.37 \\
\hline $\mathrm{T}_{7} 1 / 2$ NPK + Biopower (BP) & 2.35 & & 2.71 & & 2.67 & 2.77 \\
\hline $\mathrm{T}_{8} 1 / 2 \mathrm{FYM}+$ Biopower & 2.25 & & 2.31 & & 2.46 & 2.50 \\
\hline $\mathrm{T}_{9} 1 / 2 \mathrm{NPK}+1 / 2 \mathrm{FYM}+\mathrm{BP}$ & 2.20 & & 2.24 & & 2.41 & 2.51 \\
\hline \multicolumn{7}{|c|}{ Prices of mineral and organic/biofertilisers in $2004-06$ for VCR } \\
\hline Urea & (50 kg bag) & Rs.468.0 & & (US \$ 7.8) & & \\
\hline Diammonium phosphate & (50 kg bag) & & & (US \$13.35) & & \\
\hline Triple super phosphate & (50 kg bag) & Rs. 801.0 & & (US \$13.35) & & \\
\hline Sulphate of potash & & Rs.996.0 & & (US \$16.6) & & \\
\hline Farmyard maure & & Rs.1200.0 & & (US \$ 20) & & \\
\hline $\begin{array}{l}\text { Biofertilizer Biopower } \\
\text { (US } \$ 1.0=\text { Rupees } 60 \text { during } 2\end{array}$ & $\begin{array}{l}\text { (1.0 kg packet) } \\
2004-2006)\end{array}$ & Rs.100.0 & & (US \$1.6) & & \\
\hline
\end{tabular}

CS = cropping system; biofertiliser Biopower (seed inoculation at sowing); NPK @ 120-90-60 kg/ha; FYM (farm yard manure), @ 20 t/ha; FYM* = N equivalent + P make up dose.

alone or their integrated use may improve yield but cannot compete mineral sources for sustaining crop productivity (Table 6). There is no scope for reducing the consumption of chemical fertilisers but due to their increasing cost and environmental concerns, chemical fertilisers may not be used since integrated use of fertilisers is showing a profitable VCR (CIMMYT, 1988). The VCR values of 2.20 and 2.41 were calculated for $\mathrm{CS}_{1}$ while 2.24 and 2.51 for $\mathrm{CS}_{2}$ were calculated in 2004-2005 and 2005-06, respectively, in $\mathrm{T}_{9}$. The VCR estimated for IPNM in $\mathrm{T}_{9}$ showed that integrated use of organic and inorganic fertiliser sources had better net profit for wheat yield for the farmer under rainfed conditions. Thus, IPNM may prove more viable and sustainable for wheat based cropping systems in rainfed Pothowar area of Punjab province of Pakistan.

\section{Conclusion}

The investigations presented in this study indicate distinct benefits of IPNM over the use of mineral fertilisers. The results of this study showed that integrated use of NPK (60-45-30) kg/ha and farmyard manure @ 10 t/ha with biofertiliser 'Biopower' as in $\mathrm{T}_{9}$, was most appropriate and economical for better yield of wheat in wheat based cropping systems of rainfed areas. The results confirm that besides increasing the crop yield, IPNM saved mineral fertilisation which had potential effects on sustainable agricultural production in less fertile soils of rainfed Pothwar region of Pakistan. The high concentration of minerals in wheat plants demonstrated more efficient use of the applied mineral nutrients by IPNM in both the cropping systems. However, more intensive and systematic studies are required to provide better understanding of the usefulness of IPNM in making crop production more profitable and income generating activity for small farmers of rainfed Pothwar region of Pakistan. Integrated plant nutrient approach is going to be the mainstay in the next millennium.

\section{References}

Ahmad, R., Naveed, M., Aslam, M., Zahir, Z.A., Arshad, M., Gilani, G. 2008. Economizing the use of nitrogen fertilizer in wheat production through enriched compost. Renewable Agriculture and Food System, 23: 243-249.

Ahmad, S.I., Abbasi, M.K., Rasool, G. 2002. Integrated plant nutrition system (IPNS) in wheat under rainfed conditions of Rawalakot, Azad Jammu and Kashmir (Pakistan). Pakistan Journal of Soil Science, 21: 79-86. 
Ahmed, S., Naz, S.Y., Raja, M.R. 1998. Effect of farm yard manure, crop residues and mineral fertilizers on wheat yield under rainfed conditions. Pakistan Journal of Soil Science, 14: 111-113.

Alam, S.M., Shah, S.A. 2003. Effect of individual versus integrated use of phosphatic fertilizer on P uptake and yield of maize and wheat. Pakistan Journal of Soil Science, 22: 74-80.

AOAC 1982. Official Methods of the Association of Official Analytical Chemists, W. Horwitz (ed.), pp. 15-18, $12^{\text {th }}$ edition. Association of Official Analytical Chemists, Washington DC., USA.

Bakhsh, A., Gurmani, A.H., Bhatti, A.U. 2001. Effect of NPK and organic manures on the yield of wheat and paddy. Pakistan Journal of Soil Science, 19: 27-31.

Bakhtiar, S.M., Alam, M.J., Mahmood, K., Rehman, M.H. 2002. Integrated nutrient management under three agro-ecological zones of Bangladesh. Pakistan Journal of Biological Science, 5: 390393.

Benbi, D.K., Biswas, C.R., Bawa, S., Kumar, K. 1998. Influence of farmyard manure, inorganic fertilizers and weed control practices on some soil physical properties in a long term experiment. Soil Use and Management, 14: 52-54.

Bhatti, A.U. 2006. Restoring crop productivity of eroded lands through integrated plant nutrient management (IPNM) for sustained production. Final Technical Report 2003-2006, Pakistan Science Foundation Research Project, Department of Soil and Environmental Sciences, NWFP Agriculture University Peshawar, Pakistan.

Chatha, T.H., Yousaf, M., Javed, S. 2006. Phosphorus adsorption as described by Freundlich adsorption isotherms in relation to plant growth under rainfed conditions of Pakistan. Pakistan Journal of Agricultural Sciences, 43: (1-2).

CIMMYT, 1988. Centro Internacional de Mejoramiento de Maízy Trigo. An Economic Training Manual: From Agronomic Data to Farmer Recommendations. International Maize and Maize Improvement Center (CIMMYT), pp. 1-25, Mexico, USA.

Hafeez, F.Y., Hameed, S., Zaidi, A.H., Malik, K.A. 2002. Biofertilizers for sustainable agriculture. In: Techniques for Sustainable Agricultural, F. Azam, M. M. Iqbal, C. Inayatullah and K. A. Malik (eds.), pp. 67-73, NIAB, Faisalabad, Pakistan.

Hati, K.M., Swarup, A., Dwivedi, A.K., Misra, A.K., Bandyopadhyay, K.K. 2007. Changes in soil physical properties and organic carbon status at the topsoil horizon of a vertisol of central India after 28 years of continous cropping, fertilization and manuring. Agriculture, Ecosystems and Environment, 119: 127-134.

Jadoon, M.A., Bhatti, A.U., Khan, F., Sahabzada, Q.A. 2004. Effect of farmyard manure in combination with NPK on the yield of maize and soil physical properties. Pakistan Journal of Soil Science, 22: 47-55.

Khaliq, A., Abbasi, M.K., Hussain, T. 2006. Effects of integrated use of organic and inorganic nutrient sources with effective microorganisms (EM) on seed cotton yield in Pakistan. Bioresource Technology, 7: 967-972.

Khanum, M., Rahman, M.M., Islam, M.R. 2001. Effect of manures and fertilizers on growth and yield of BRRI Dhan 30. Pakistan Journal of Biological Sciences, 4: 172-174.

Koehler, F.E., Moudre, C.D., McNeal, B.L. 1984. Laboratory Manual for Soil Fertility. Washington State University, Pulman, USA.

McLean, E.O. 1984. Soil pH and lime requirement. In: Methods of Soil Analysis, A. L. Page, R. H. Miller and D. R. Keeney (eds.), pp. 199-209, American Society of Agronomy No. 9. Madison, Wisconsin, USA.

Nelson, S.W., Sommers, I.E. 1982. Total carbon, organic carbon and organic matter. In: Methods of Soil Analysis: Part 2. Chemical and Microbiological Properties, A. L. Page (ed.), pp. 539-580, American Society of Agronomy, Madison, WI, USA.

Nawaz, S., Hussain, R., Aslam, M., Chaudhry, G.A., Ahmad, Z., Akhtar, J. 2000. Integrated use of organic and chemical fertilizers on wheat under rain-fed conditions. In: Proceedings of Symposium on Integrated Plant Nutrition Management, pp. 223-230, NFDC, Islamabad, Pakistan.

Ouedraogo, E., Mando, A., Zombre, N.P. 2001. Use of compost to improve soil properties and crop productivity under low input agricultural system in West Africa. Agriculture Ecosystems and Environment, 84: 259-266.

Rashid, M., Bashir, S., Akhtar, K. 1998. Plant nutrient management under rainfed conditions. In: Proceeding of Symposium on Plant Nutrients Management For Sustainable Agriculture Growth, pp. 111119, NFDC, Islamabad, Pakistan.

Ryan, J., Stefen, G., Rashid, A. 2001. Soil and Plant 
Analysis Laboratory Manual, 172 pp., $2^{\text {nd }}$ edition, International Center for Agricultural Research in Dry Areas ( ICARDA), Aleppo, Syria.

Sokal, R.R., Rohlf, F.J. 1997. Biometry: The Principles and Practice of Statistics in Biological Research, $3^{\text {rd }}$ edition, W. H. Freeman and Company, New York, USA.

Soltanpour, P.N., Schwabe, A.P. 1977. A new soil test for simultaneous extraction of macro and micronutrients in alkaline soils. Communications in Soil and Plant Analysis, 8: 195-207.

Soumare, M., Tack, F.M.G., Verloo, M.G. 2003. Effects of a municipal solid waste compost and mineral fertilization on plant growth in two tropical agri- cultural soils of Mali. Bioresource Technology, 86: $15-20$.

Singh, G.B., Swarup, A. 2001. Lessons from long term fertility experiments. Fertilizer News, 45: 13-24.

Wu, S.C., Cao, Z.H., Li, Z.G., Cheung, K.C., Wong, M.H. 2005. Effects of biofertilizer containing $\mathrm{N}$-fixer, $\mathrm{P}$ and $\mathrm{K}$ solubilizers and AM fungi on maize growth: a greenhouse trial. Geoderma, 125: 155-166.

Yaduvanshi, N.P.S. 2003. Substitution of inorganic fertilizers by organic manures and the effect on soil fertility in rice-wheat rotation on reclaimed sodic soil in India. Journal of Agricultural Science, 140: 161-168. 